\title{
Effects of Green Roofing Treatment on Indoor Thermal Performance of Mid-Rise Residential Apartment Buildings: A Case Study of Dhaka, Bangladesh
}

\author{
Anika Tabassum ${ }^{1 *}$, Priyanka Baten ${ }^{2}$ and Atiqur Rahman ${ }^{3}$ \\ Department of Architecture, Bangladesh University of Engineering and Technology, Dhaka, Bangladesh
}

\begin{abstract}
Rapid rate of urbanization and population growth has tremendously increased energy consumption of buildings in Bangladesh. Implementation of sustainable design and construction with appropriate building materials can significantly reduce building energy consumption. The installation of green roof technology in buildings as a means of delivering passive cooling can be a potential solution. The aim of this research was to investigate and compare the effects of green roofing technology on the ambient indoor air temperature of mid-rise residential apartment buildings in tropical Dhaka city. Extensive field work was conducted in two phases: residential buildings with roofs having potted plants and residences with bare flat concrete roofs. It was considered that the interior ambient temperature of the space in the floor below the roof provided an indicator of performance of the roof material. From the study findings and analysis, it is observed that average indoor ambient air temperature drops significantly by $2.78^{\circ} \mathrm{C}$ for roofs with potted plants, compared to bare flat concrete roofs, which reduce indoor temperature by a mere $0.34{ }^{\circ} \mathrm{C}$. The research concludes with recommendations about sustainable roof design and construction which would help decrease pressure on energy demands, and thus help generate more sustainable residential environments in Dhaka.
\end{abstract}

Keywords: green roof, ambient air temperature, sustainable method, passive cooling

\section{Introduction}

Global warming due to ongoing climate changes has become an extremely critical issue on an international basis. Due to its biophysical factors (flat, low-lying delta) and socio-economic factors (for example high dependence on agriculture, high population density and poverty rates), Bangladesh is particularly susceptible to the impacts of extreme weather events, including significant increase in mean annual temperature (Rahman, 2019, Government of the Netherlands, 2018, Elahi and Khan, 2015, Hasan and Rahman, 2013). Current statistics stemming from weather reports of Bangladesh have displayed more erratic and unpredictable trends than data which had been collected over past decades (Figure 1) (Basak et al., 2013, Glennon, 2017, Shajahan, 2012). Average outdoor air temperatures in Bangladesh have increased in recent times, with significant changes being observed during the monsoon season (June-August) at $0.07^{\circ} \mathrm{C}$ per decade and during early winter (September-November) at $0.12^{\circ} \mathrm{C}$ per decade (Government of the Netherlands, 2018). Future climate change projections of Bangladesh shown in Figure 2 also signify that mean annual temperatures will continue to increase by $1.8^{\circ} \mathrm{C}$ near the $2060 \mathrm{~s}$ and $2.7^{\circ} \mathrm{C}$ by the 2090s (compared to data collected during the year 2010) (United States Agency International Development, 2015, Government of the Netherlands, 2018). 


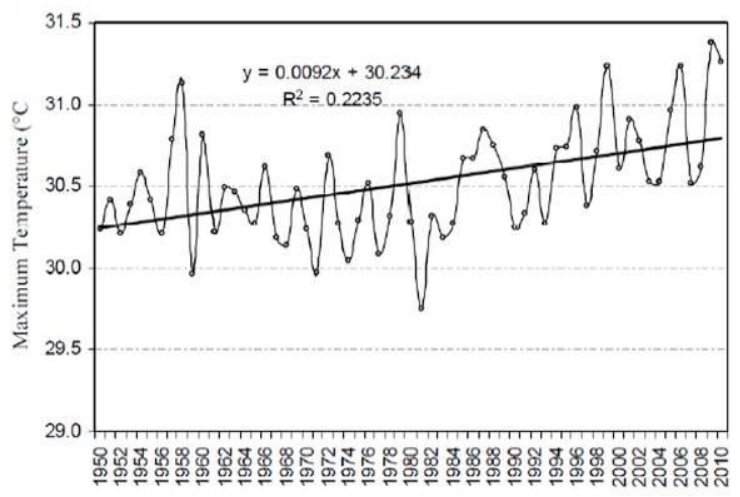

Figure 1 Temporal variation of annual maximum temperature of Bangladesh during 1950-2010. (Source: Bangladesh Meteorological Department, 2012)

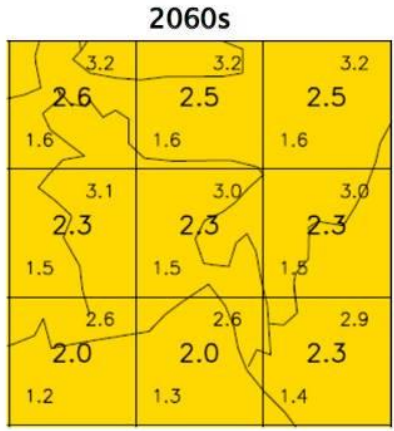
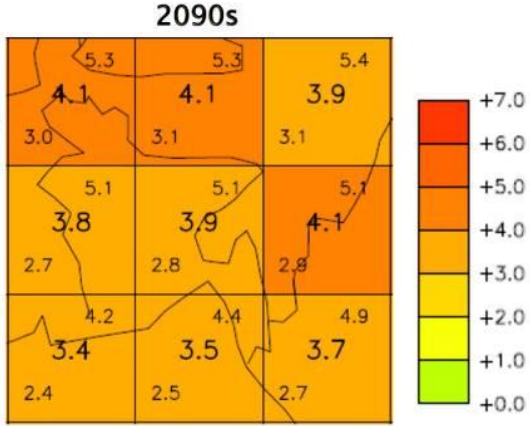

Figure 2 Projected change in mean annual temperature, relative to the 1970-2000 mean climate. (Source: Karmalkar et al., 2012)

Rapid rate of vertical and horizontal urban growth has significantly diminished green areas and vegetation from the surrounding environment, which in turn has adversely affected the urban microclimate (Doulos et al., 2004). According to a study conducted during 2011, the total percentage of open space area in Dhaka have decreased to around $14.5 \%$ (Dewan et al., 2010). Additionally, densely located urban buildings consisting of variable vertical heights create an irregular urban texture, resulting in the accumulation of excess heat within the built environment (Ahmed and Roy, 2007). This has contributed towards various negative impacts on the surrounding environment such as Urban Heat Island (UHI effect) (Rashid and Ahmed, 2009, Tashnim and Anwar, 2016, Abudu and Parvin, 2017, Hossain and Latifee, 2018). Residential areas currently form the highest composition (44.35\%) of total built up land coverage in Dhaka city (Japan International Cooperation Agency, 2010).

Urban microclimate changes in Dhaka city have been affecting the physical comfort of inhabitants and users of residential spaces in terms of thermal conditions, resulting in increased energy usage for achieving thermal comfort (The World Bank, 2018). However, there has been a growing difference between power generation $(4.5 \mathrm{MW})$ and demand $(6.5 \mathrm{MW})$ among local residences, causing infrequent power-cuts, especially during the hot periods of summer (Tariq and Ahmed, 2013, The World Bank, 2011, Istiaque and Khan, 2018). Additionally, electricity consumption in Dhaka was found to be the highest for residential buildings, and this conspicuous trend often tends to peak during the season of summer (Figure 3) (Istiaque and Khan, 2018). 


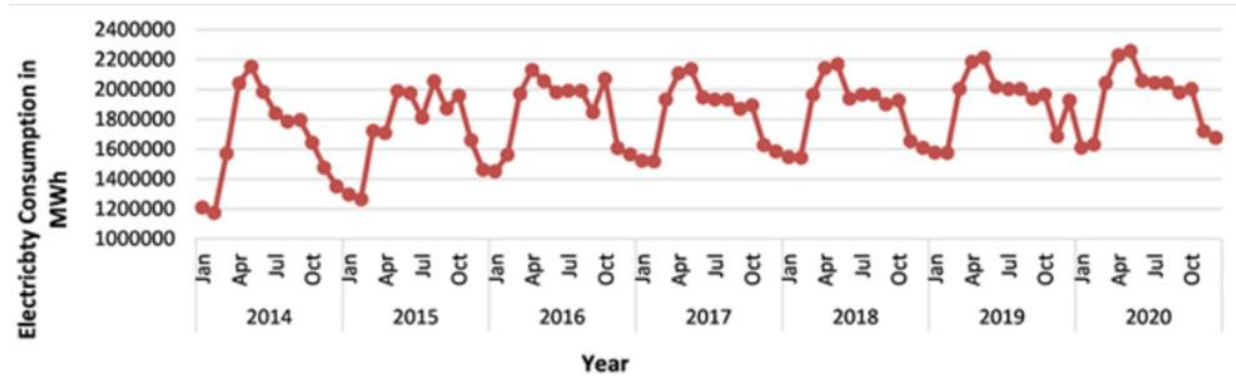

Figure 3 Monthly electricity consumption from January 2014 to December 2020 for Dhaka city. (Source: Istiaque and Khan, 2018)

Most of the residential buildings located in Dhaka city usually consist of flat concrete rooftops in their construction (Mridha, 2002). In tropical climatic areas like Dhaka, roofs receive the highest amount of solar radiation during any part of the day (approximately $5329 \mathrm{Wh} / \mathrm{m} 2$ ), as it is the building component which tends to be the most exposed to the outside climatic elements (Mridha, 2002, Ahmed, 1994, Ahmed, 1987). This results in a significant increase in transfer of heat energy in the floor located directly below the roof, and hence increase in the indoor air ambient temperature. Residential units located directly below the roof and on consequent upper levels display an inclination to have higher ambient indoor temperatures compared to units located on lower levels, due to closer proximity to rooftop (Ponni and Baskar, 2015). This contributes to a decrease in thermal comfort of occupants especially those inhabiting upper floor levels, leading to increased consumption of nonrenewable energy sources for active cooling purposes as shown in Figure 4 (Berkovic et al., 2012). Ambient air temperature is the most important environmental factor and main criterion for evaluating thermal comfort of human beings (Mridha, 2002). In summer months, mean air temperatures in Dhaka can soar as high as $37^{\circ} \mathrm{C}$, which exceeds the thermal comfort level of $25^{\circ} \mathrm{C}$ to $30^{\circ} \mathrm{C}$ generally experienced by inhabitants of south-Asian regions, and the comfort zone of $24.6^{\circ} \mathrm{C}$ to $28.6^{\circ} \mathrm{C}$ for Dhaka residents (Karyono, 1996, Humphreys et al., 2015).

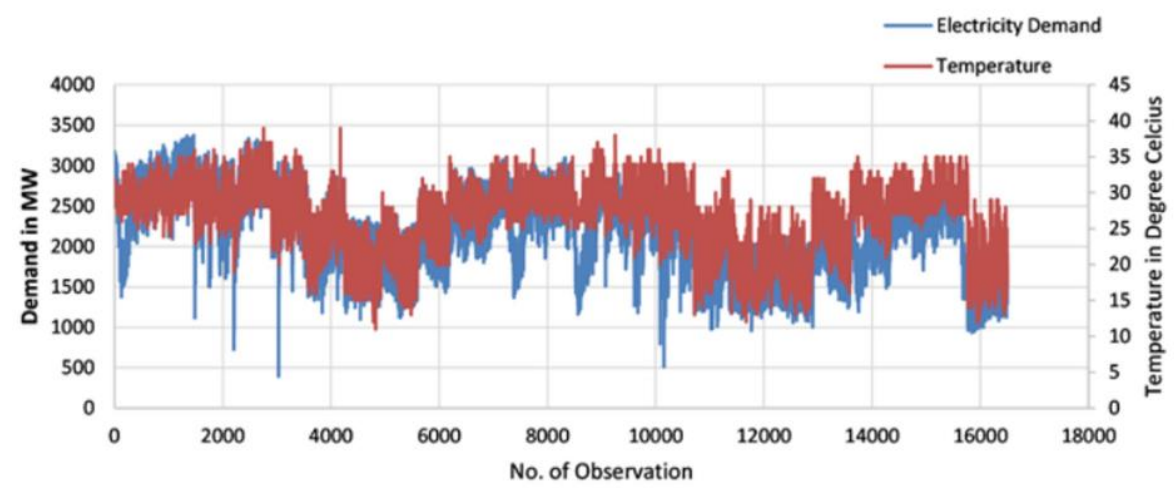

Figure 4 Demand vs. Temperature Curve of Dhaka city of 47 months (January 2014-July 2017). (Source: Istiaque and Khan, 2018)

Passive techniques and appropriate construction methods for ensuring indoor thermal comfort of users is the ideal solution for reducing dependency on non-renewable energy resources. Green roofs are an efficient means for reducing the need of air conditioning in summertime, resulting in increase in the rate of energy saving in buildings (Liu and Baskaran, 2003, Rosenzweig et al., 2006). Green roofs also tend to perform better during summer time compared to the winter, due to its increased ability of reducing heat gain rather than heat loss (Liu, 2006). It is regarded as the structural integration of plantation and vegetation space on the top of a roof. Green roofs preserve rainwater in order to evaporate the collected moisture, releasing latent heat and reducing sensible heat which is referred to as the heat felt by building occupants (U.S. Environmental Protection Agency, 2018). It 
also removes heat from the surrounding air and reduces heat absorption by roof surface, causing a decrease in surrounding air and roof surface temperature (Shishegar, 2012). Various studies have indicated about the benefits of green roof on contributing to significant reduction in indoor ambient air temperature and enhancing living environment for inhabitants (U.S. Department of the Interior, n.d., Kamarulzaman et al., 2014, Jim, 2015, Cascone, 2019, Niachou et al., 2001). Green roof also provides with various other benefits such as aesthetical and recreational opportunities, storm water management, UHI mitigation, acoustical and heat insulation, reduction in carbon dioxide, economic benefits, air filtration, improving water quality and conserving energy (Mowla, 2010).

Green roofing construction can provide a sustainable urban future by reintroducing nature into the city. "Retrofitting" of a traditional green roof onto an existing roof has to consider the roof's defects, such as existing leaks, damage and inability to resist roots. However, a basic flat concrete roof can easily be transformed with the arrangement of container plantings. Any type of plants can be planted in lightweight containers made from plastic, wooden boxes, plastic bags or metal pots. Lightweight growing medium is typically used for any type of rooftop plantation in order to help reduce overall load (Wilkinson and Feitosa, 2015). The soil content of potted plants also increases the thermal capacity insulation value, adding efficiency in reducing indoor ambient air temperatures (U.S. Environmental Protection Agency, 2018, Han, 2019, Ismail et al., 2010).

\section{Problem statement}

Residential buildings located in dense tropical Dhaka city consume around $85 \%$ of the total electricity conserves, which is the highest among all building typologies according to the energy consumption data reports of Dhaka (Tariq and Ahmed, 2013, Istiaque and Khan, 2018). Even though overheating of indoor residential spaces has continued to be a rising environmental concern for tropical cities like Dhaka, rules and regulations to achieve thermal comfort for inhabitants in residential environments are currently absent in Dhaka's local building codes. Thermal performance of residential buildings through appropriate choice of roofing material and construction techniques should be of utmost priority - as it would aid in modelling energy transfer between building and surrounding environment (Ponni and Baskar, 2015).

Retrofitting of intensive or extensive green roof in residential buildings can be expensive. However, installation of container or potted plants on rooftops is a sustainable, economical and familiar concept which already is typically followed in residences of tropical cities, including Dhaka. In Dhaka city, the potential for implementing green roof construction in buildings, including residences, are significant. However, potential for integrating green roof technology in residences of Dhaka has not yet been investigated at large and thus remains untapped. Additionally, standards for development of sustainable roof design and construction methods appropriate to the context of Dhaka city are currently absent.

\section{Objectives of the research}

The main aim of this research was to investigate the effectiveness of potted green roofing treatment and its potential to achieve passive thermal control, inside mid-rise residential apartment buildings during warm-humid season in Dhaka city. It includes objectives which focus on evaluating the performance of potted plants on reducing indoor ambient air temperature, comparing the effects of roof potted plants with basic flat concrete roof and assessing the deviations in cooling performance between these two roof types.

\section{Methodology of the research}

In order to frame the knowledge base, previous thermal performance researches which were relevant to the climatic context of Dhaka have been reviewed. The selection of case buildings for the research was carried out by typical case sampling technique. As the study focuses on typical residential building typology in Dhaka, all 
the case buildings were selected based on the likelihood of having the same physical characteristics (Etikan et al., 2016). The benchmarks for choosing the sites and buildings were as follows:

- The sites should be located within the urban boundary and contain typical urban fabric characteristics of Dhaka.

- The buildings should be around, if not the same height.

- The buildings should always receive constant, uninterrupted direct solar radiation and should not be overshadowed by other buildings during any time of the day.

After the survey of twenty residential buildings, eight mid-rise residential apartment buildings consisting of four to eleven stories were selected for this research. Four of these residences had potted plants on their rooftops, while the rest consisted of bare flat concrete roof. For each case study, measurements of air temperature (average value of five readings) were made using Extech45118 model mini Thermo-Anemometer and were recorded at three different positions:

- A1: Outside temperature (1 $\mathrm{m}$ above roof surface)

- A2: Temperature at roof surface

- A3: Temperature of indoor space (1 $\mathrm{m}$ above floor surface inside the room immediately below the roof surface)

For each case study, all readings were taken from same vertical position in the floor plan. The central room of each case study was chosen for this purpose so that the parapet wall of the building had no impact on temperature readings by means of introducing shadows in those spaces. It was considered that the air temperature difference between A2 (temperature at roof surface) and A3 (temperature of interior space) would provide a significant indicator of the performance of the respective roof composition.

Readings were taken in the month of April 2019, which was considered to be an overheated period during that year. Measurements were done at around 2 P.M. and for three days for each case study. These days were characterized by clear skies, dry weather, high solar altitude angle, high solar intensity and high duration of sunshine. Local meteorological station database was used for collecting information on solar radiation, relative humidity, wind speed and air temperature.

The research was primarily based on instrumental survey measurements, discussion with residents, observations, and comparison and analysis of final data. In order to minimize the impact of surroundings on the temperature variations and considering the limited period of time which was available for the research, residential areas of similar physical features were chosen. While taking readings indoor, the anemometer was held each time as close to the ceiling as possible by using an extendable standing tripod. This was to cancel the effects of radiation generating from glazing, wall and neighboring materials. Mechanical devices for ventilation, heating and cooling such as ceiling fans, indoor heaters and air conditioning units were switched off while recording the temperature readings.

\section{Field investigation}

The eight survey spots were based on the flat concrete roof, having an average thickness of $152.4 \mathrm{~mm}$. Case studies A, B, C and D consisted of green roofs (in terms of potted plants), and case studies E, F, G and H consisted only of the basic flat concrete roof. Figures inset in Table 1 below show the positions at which the three sets of temperatures were measured and recorded for each of the eight cases, in addition to their location in Dhaka city and general surroundings. During the total twenty-four days of survey, relative humidity (62\%) remained nearly constant. Wind speed was observed to be variable during this time frame. The average time period of rooftop gardening for case studies A, B, C and D was ten years. 
Table 1 Roof height, location and general surroundings of selected case studies. (Source: Author)
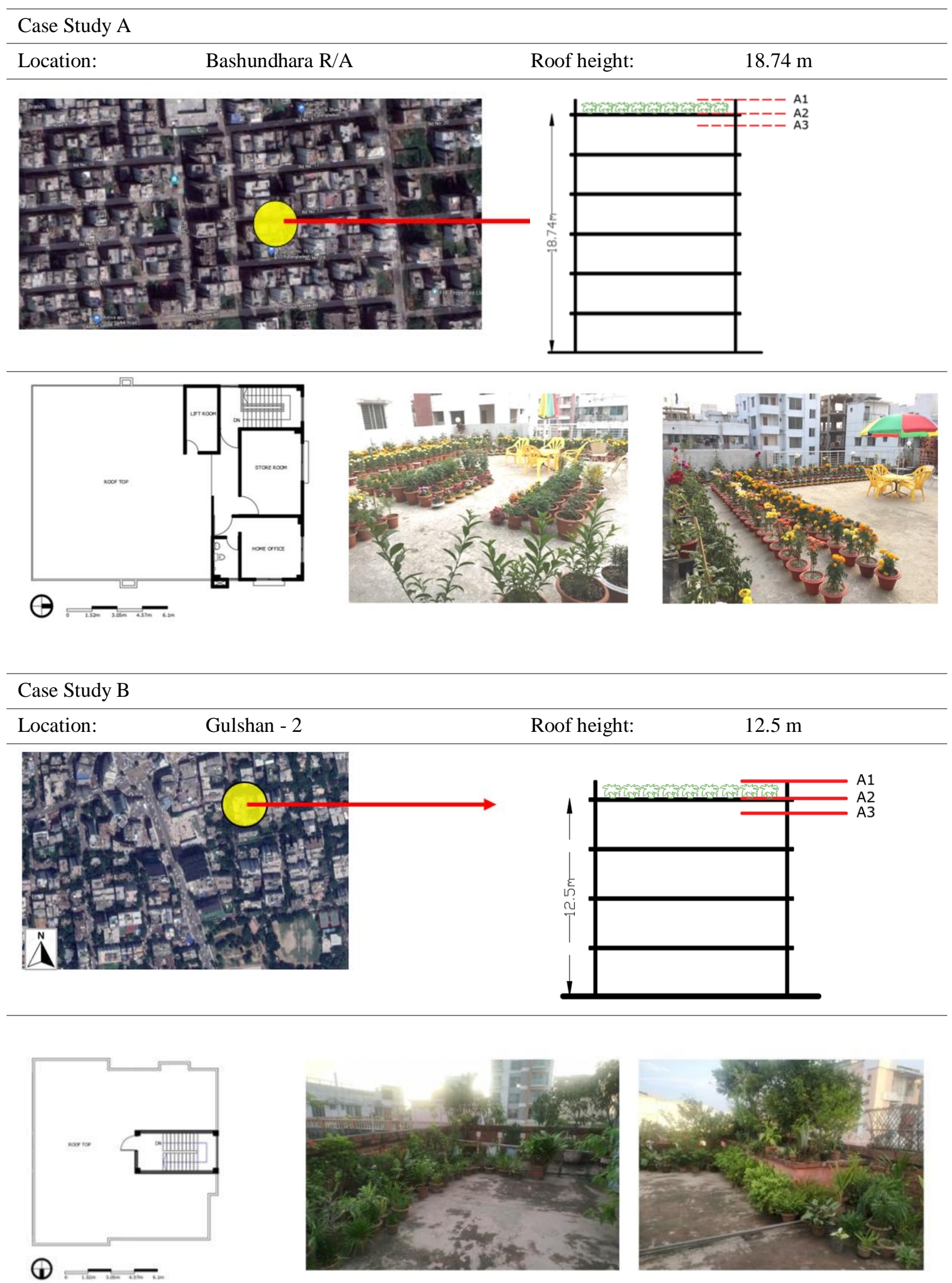

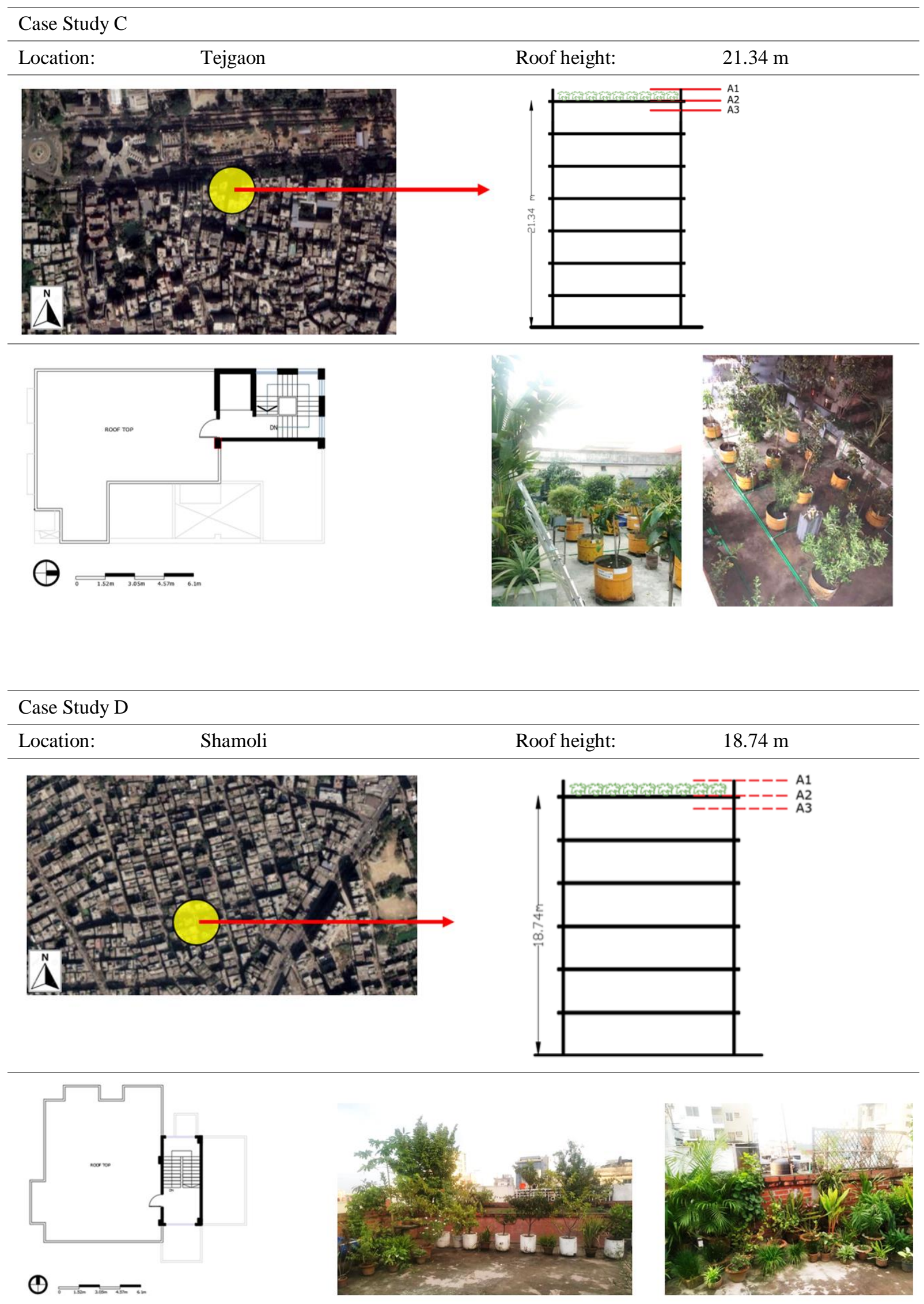
Case Study E

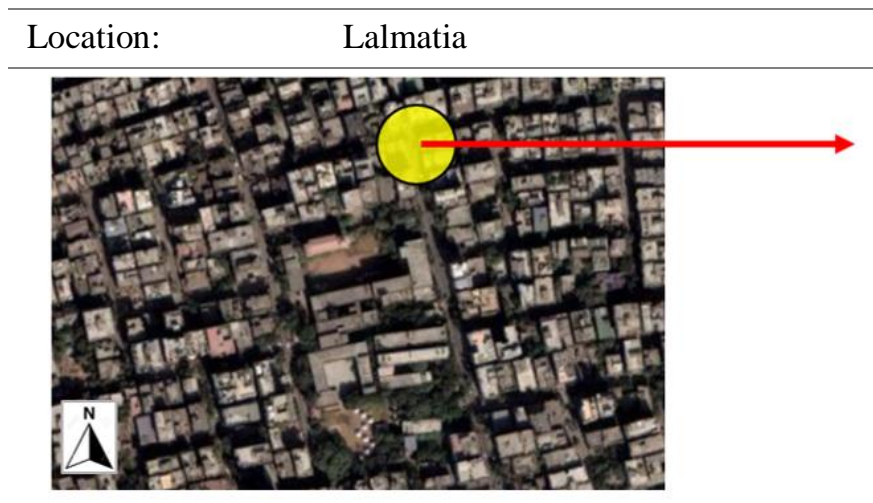

Roof height: $\quad 18.74 \mathrm{~m}$
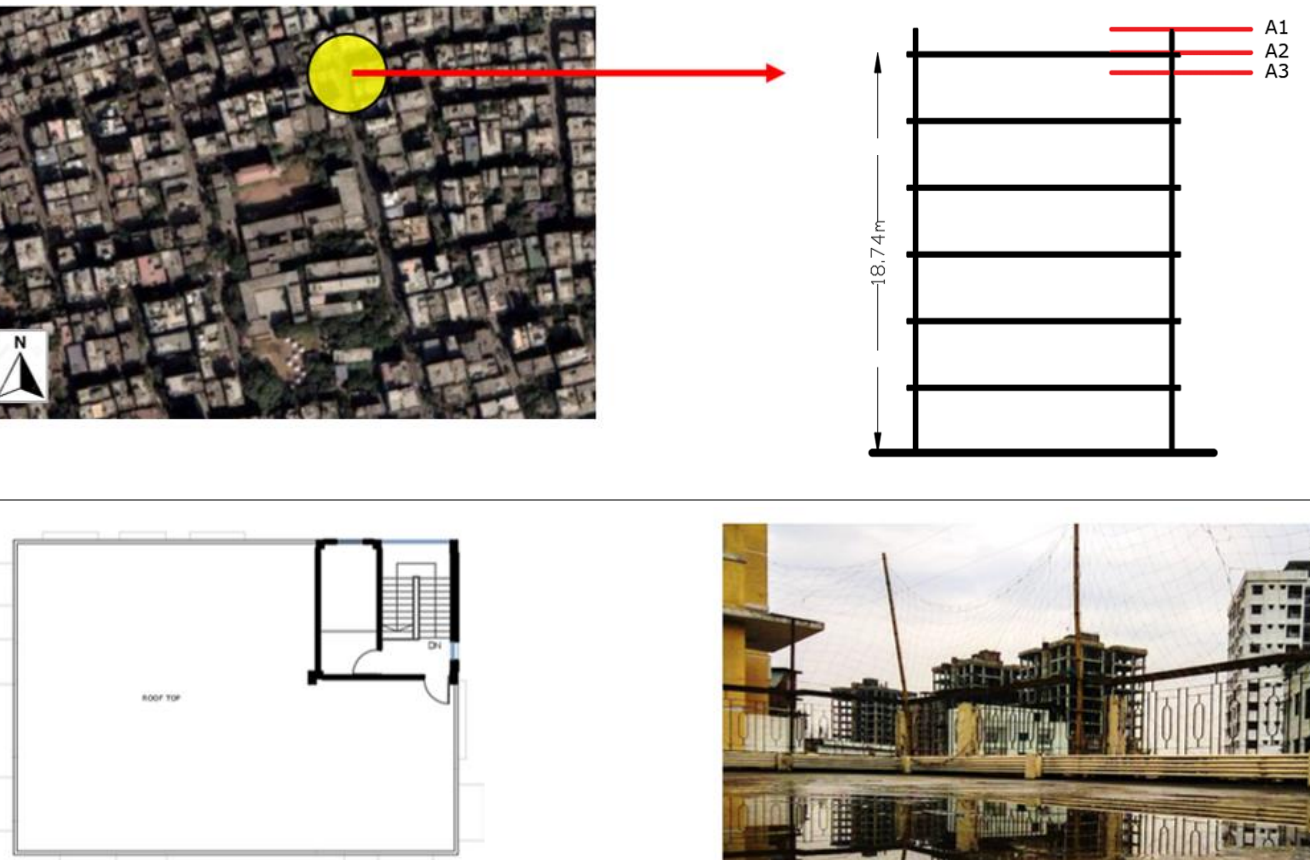

$\theta=-$
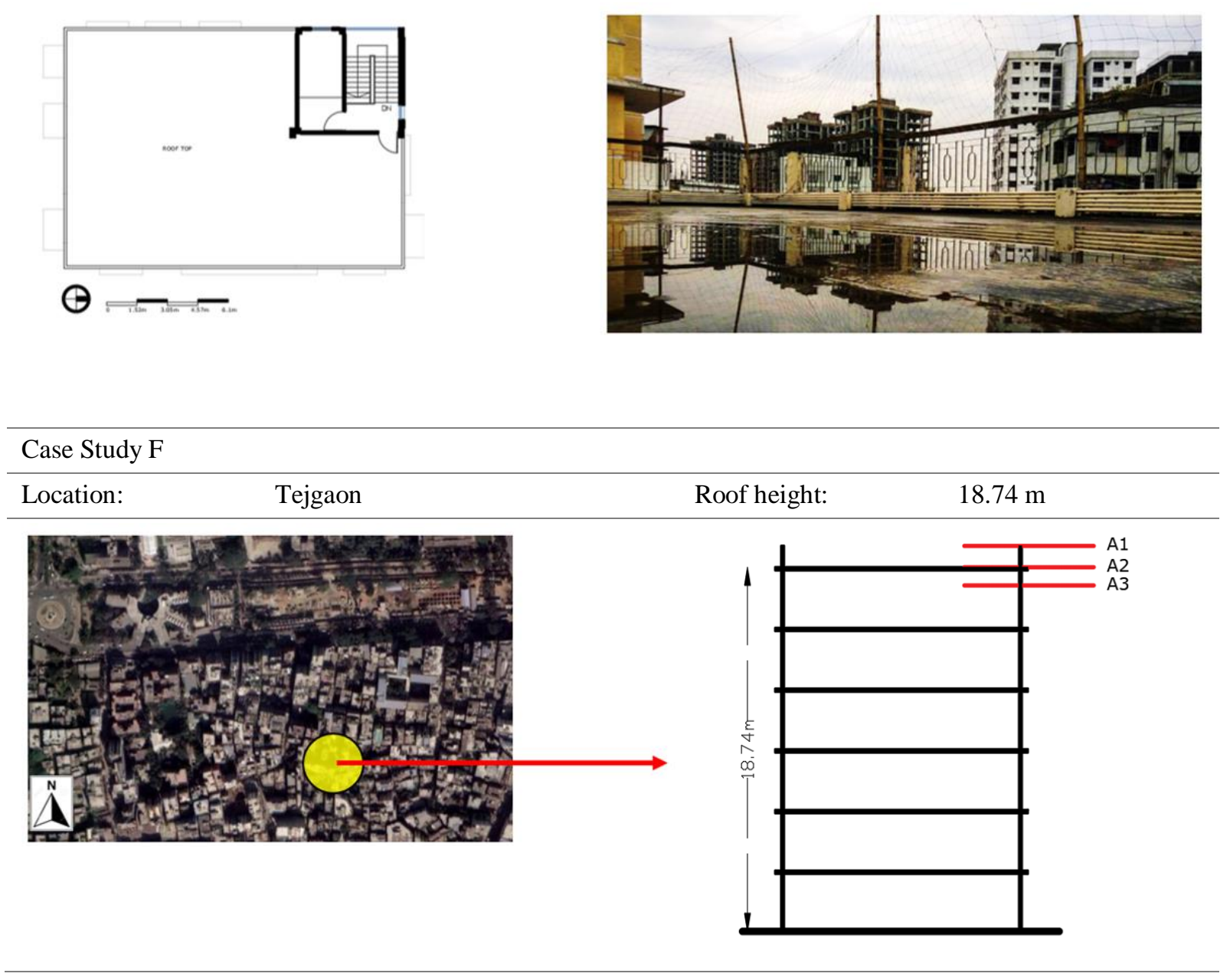


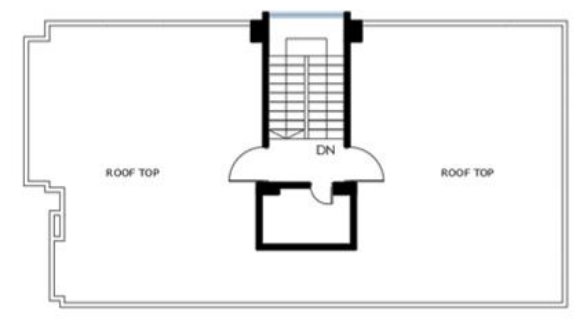

$\Theta$
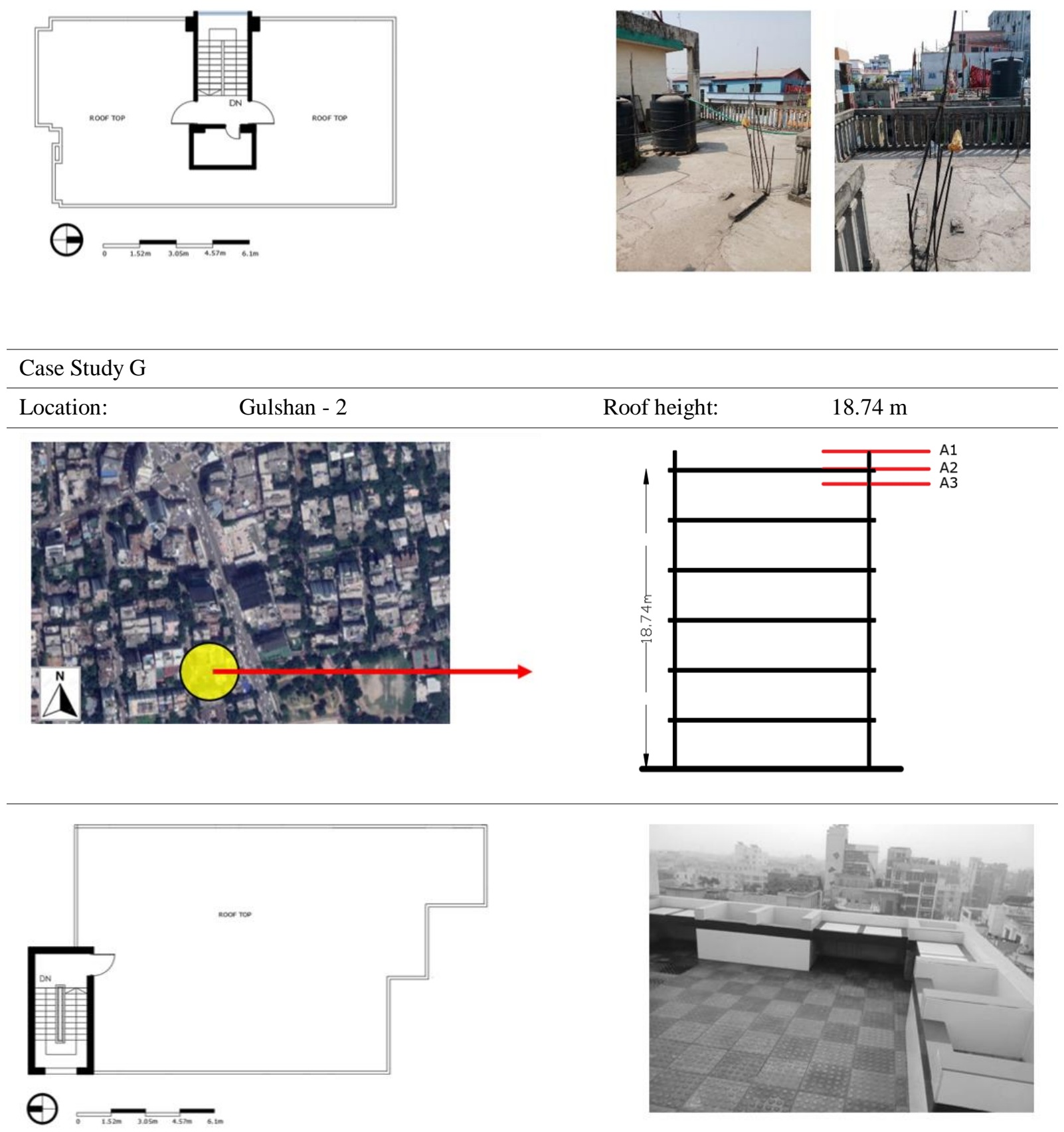

Case Study H
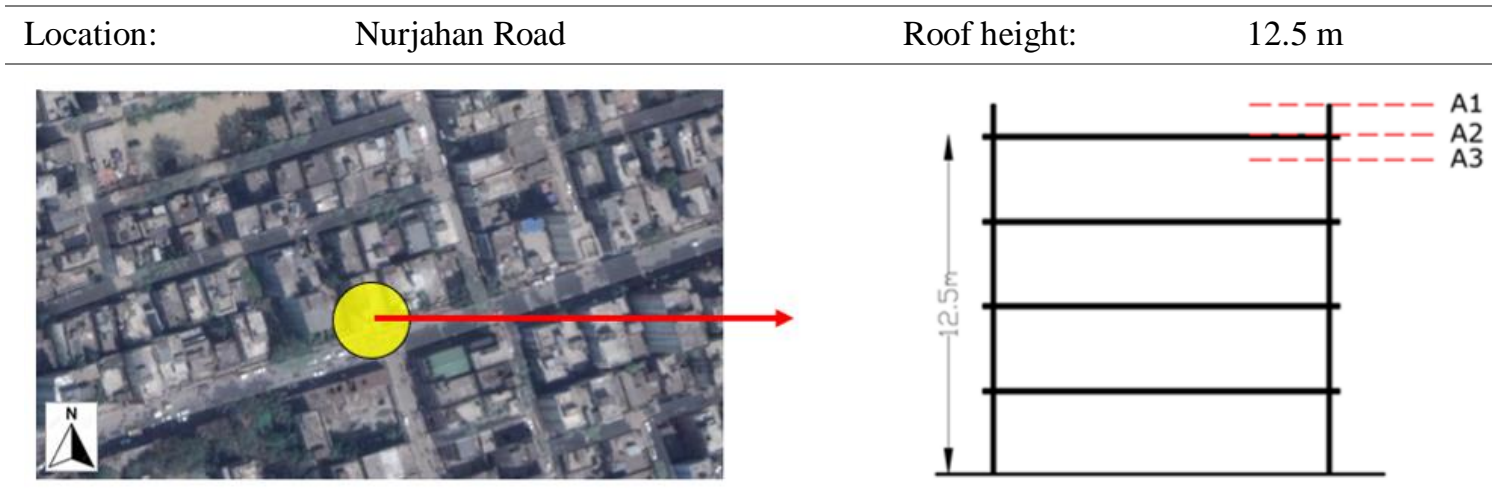

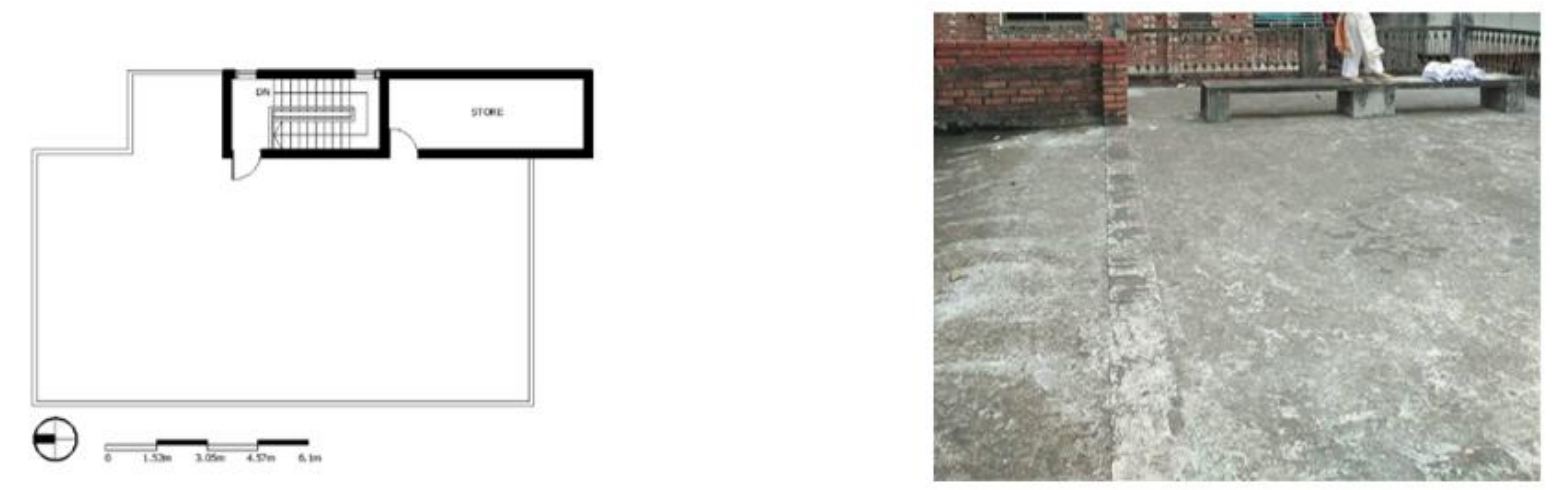

\section{Initial observations}

- Current use of residential rooftops: For case studies A, B, C and D, the highest percentages of floor areas expressed by the respondents which was being used for roof top gardening was $88.6 \%$, drying cloths $27.8 \%$ and other activities (for example playing, walking) $10.6 \%$. For case studies E, F, G and $\mathrm{H}$, none of the residents used the roof top space for gardening. $71.4 \%$ of the area was used for drying clothes, and $20.3 \%$ for other activities.

- Plants grown in case studies A, B, C and D: Most residents cultivated various vegetables, fruits and flowering plants in these rooftops. But the composition of fruits, flowers and vegetables varied significantly among the households. Fruits grown mostly included mango, lemon, guava, pomegranate, hog-plum and papaya. Vegetables included tomato, brinjal, Indian spinach, lady's fingers, chili and gourds. A significant number of seasonal flowering plants were also cultivated, including bougainvillea, rose, sunflower, dahlia, "Krishnochura" (Delonix regia), "Palash" (Butea monosperma) and Arabian jasmine.

- Containers used for gardening in case studies A, B, C and D: The most commonly used containers used for roof top gardening were plastic drums, plastic pots, earthen pots, galvanized iron sheet-made drums, plastic buckets, concrete-made drums and plastic trays.

- Potential spaces of rooftop: Average rooftop space of the eight selected case studies was recorded as 178 sq. m., where potential space for gardening was 148 sq. m. and $30 \mathrm{sq}$. m. for open space. 


\section{Temperature data analysis}

Table 2 shows the changes of temperatures for outdoor, indoor and roof surface of the eight cases over the twenty-four-day survey period.

Table 2 Changing pattern of temperatures $\left(\right.$ in $\left.{ }^{\circ} \mathrm{C}\right)$ for the selected case studies. (Source: Author)

$\rightarrow \mathrm{A} 1$ (Outside temperature) $\rightarrow \mathrm{A} 2$ (Roof temperature) $\rightarrow \mathrm{A} 3$ (Indoor temperature)

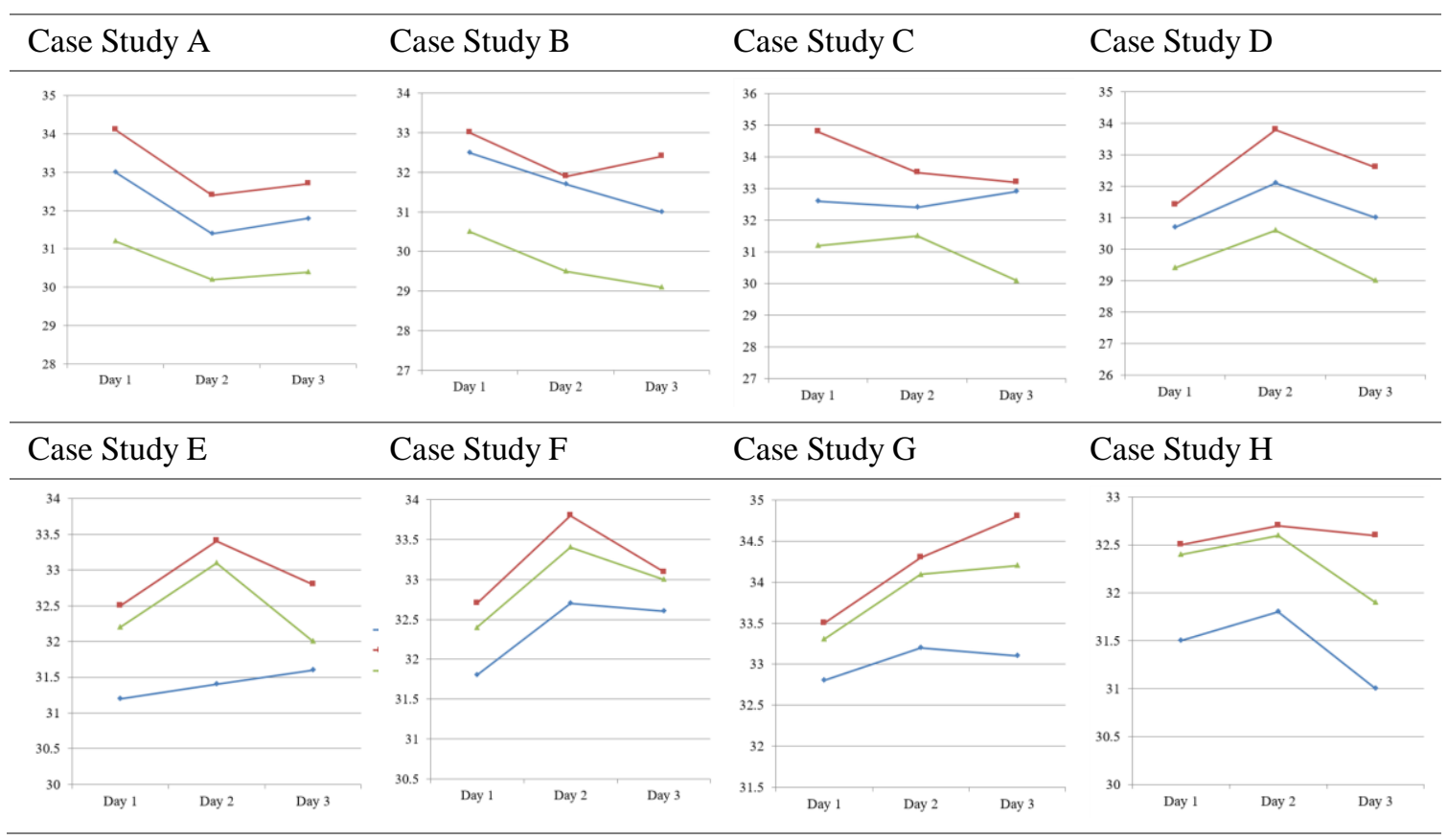

The results from Table 2 show that for roofs having potted plants (case studies A, B, C and D), indoor temperature A3 always remained lower than that outside temperature A1 and roof surface temperature A2. However, for bare flat concrete roofs (case studies E, F, G and H), the indoor temperature A3 was higher than the outside temperature A1. For all the cases, roof surface temperature was always higher than outside and indoor temperature.

\section{Comparative data analysis of temperature}

Due to the variations in outside, indoor and roof surface temperatures observed during the different days of survey, the exact values of temperature were not used for data analysis in this research. In such cases, the numerical differences between outside, indoor and roof surface temperatures were investigated instead. Hence, the performance of green roof compared to non-green roof was evaluated through the temperature difference between indoor space and roof surface. This also provided an indicator of the insulation values of respective roofs. Table 3 presents the temperature difference between indoor space and roof surface of the studied cases. 
Table 3 Temperature differences between roof surface and indoor for the studied cases. (Source: Author)

Roof with potted plants

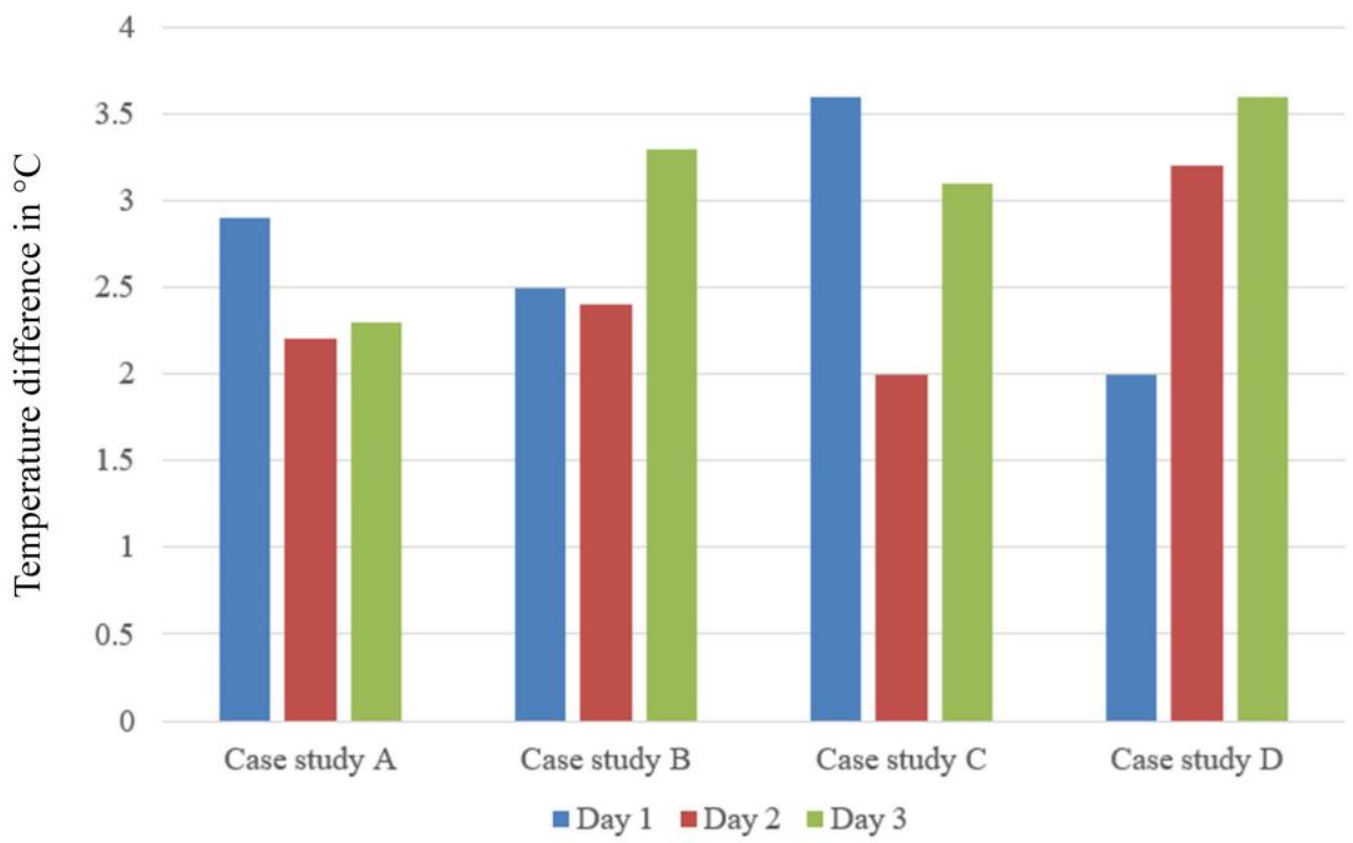

Basic flat concrete roof

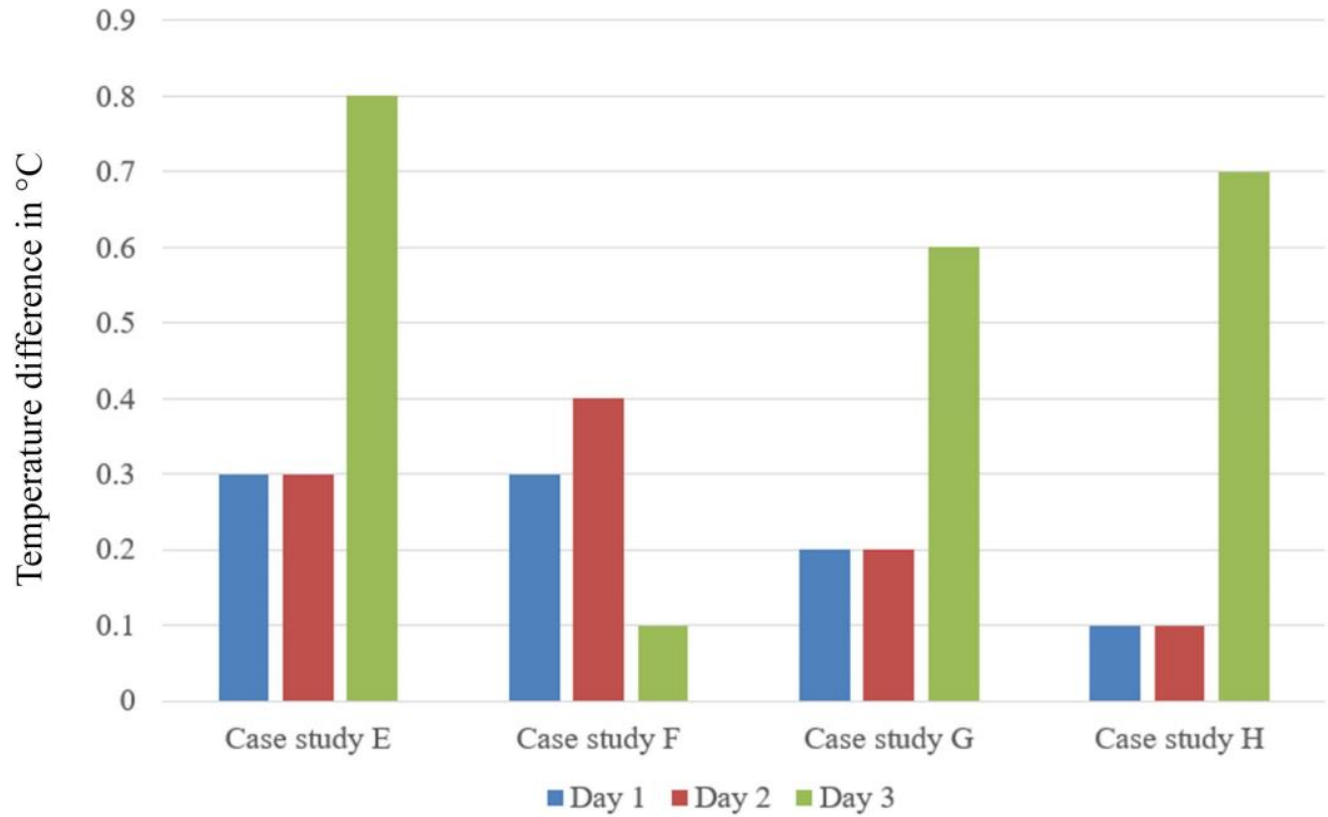

From the comparison data analysis showed in Table 3, it can be seen that roofs which had potted plants display the highest temperature difference in general, with the highest difference of $3.6^{\circ} \mathrm{C}$ shown by case studies $\mathrm{C}$ and $\mathrm{D}$ on day 1 and day 3 respectively. On the other hand, residences having basic flat concrete roofs had the lowest temperature difference, with the highest difference of only $0.8^{\circ} \mathrm{C}$ shown by case study $\mathrm{E}$ on day 3 . This implies 
that residences having only bare concrete slab without any form of green roofing treatment are less efficient in insulation of rooms adjacent to roof surface.

Figure 5 illustrates the average temperature difference between indoor and roof surface of the two roof typologies investigated in this research.

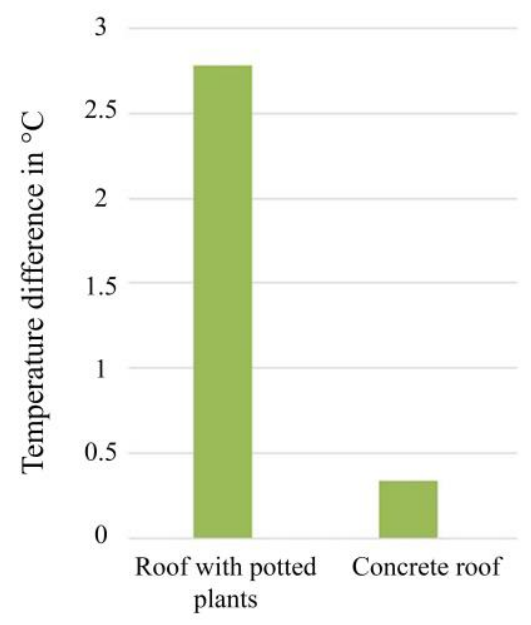

Figure 5 Temperature differences between roof surface and indoor for the two typologies of roof studied. (Source: Author)

From the comparative data analysis shown in Figure 5, it can be seen that roofs which have potted plants display the highest average temperature difference compared to case 2 (basic flat concrete roof). Roofs with potted plants display the highest efficiency at reducing internal heat gain, by lowering temperature of interior spaces from the exterior value by an average temperature difference of $2.78^{\circ} \mathrm{C}$. It can be deduced that the soil content of potted plants greatly enhances the thermal capacity insulation value and increase the efficiency in reducing internal ambient air temperature. Basic flat concrete roof is found to be the most inefficient at reducing internal heat gain of adjacent spaces, lowering the temperature by an average value of only $0.34{ }^{\circ} \mathrm{C}$.

\section{Potted plants for urban residential rooftops}

Most of the rooftops of urban residences in Dhaka are flat and easily accessible. Thus, they are suitable for any form of rooftop gardening, including potted plants. The climate of Dhaka city is also suitable for growing various types of potted plants on rooftop. As potted or container plants consist of incorporating non-structural planning, construction and design solutions, it can be installed on demand by urban residents. In most cases, inhabitants can incorporate potted plants in the layout of their rooftops with reduced budgetary constraints. A number of recycled materials are generally used in green roofs, such as membranes and growing mediums (for example crushed porous brick), making the process predominantly sustainable. Based on discussions with inhabitants of the case studies, it was seen that methods on container preparation for planting, fertilizer application and irrigation methods were uncomplicated and could be easily followed and replicated by any urban resident. In addition, implementing potted plants on rooftops could provide residents with production of fresh fruits and vegetables, significantly enhancing the nutritional status and budgetary savings of household members. Most of the inhabitants of residences having basic flat concrete roof also showed willingness regarding the installation of potted plants as a means of sustainable passive indoor cooling technique on their rooftops. 


\section{Conclusion}

The selection of satisfactory roof configuration has a great impact on the thermal condition of indoor spaces in urban residences. Results obtained from this investigation confirm that placing potted plants on rooftops can significantly reduce the indoor ambient air temperature of spaces underneath the roof. Instead of utilizing green roof system which consists of multiple layers, complex construction and installation measures, and large expenditures, potted plants can be incorporated on urban roof tops to reduce the demand of non-renewable energy sources.

Only buildings located within Dhaka city were investigated due to inadequate time and resources. In addition, residential areas having similar physical features were chosen, in order to reduce the influence of surroundings on the temperature deviations. It was anticipated that shadows falling from the potted vegetation acts as a buffer and aids in cooling the surrounding air temperature. However, the potted plants in the studied cases were not distributed equally across the roof top. Additionally, the studied buildings had different floor areas and space dimensions as well as different room orientations, furniture layout, building materials with different thermal properties, window pattern, and different orientation in the urban area. The buildings were occupied with inhabitants during the investigation time period, and thus human activities which may have contributed in affecting indoor thermal conditions could not be controlled.

Strategies and recommendations based on this study could be carried out for a greater number of buildings over a wider period of time for further authenticity. Further research could also be conducted by integrating factors such as structural conditions of existing buildings, maintenance cost, different types of plants, other variety of container materials, and water demand of plants during warm humid season.

The outcome of this research may be applied in rooftops of residential buildings in order to obtain enhanced thermal performance, thus helping to reduce energy consumption of Dhaka city. This research may aid in forming baseline data to be applied as a guideline for developing building codes regarding sustainable comfort conditions and construction methods for residential buildings in Bangladesh. For additional authenticity and validity, computer simulation studies may be used to cross-check with performance in real time.

\section{Acknowledgements}

The authors would like to thank the Department of Architecture, Bangladesh University of Engineering and Technology (BUET) for their support in this work. They also gratefully acknowledge the support of Bangladesh Agriculture Research Institute for their support and guidance.

\section{References}

ABUDU, D., and PARVIN, N. S., 2017, Estimating Urban Heat Island Intensity using Remote Sensing Techniques in Dhaka City. International Journal of Scientific and Engineering Research, 8(4), 289-298.

AHMED, Z. N., 1987, The Effects of Climate on the Design and Location Buildings in Bangladesh. M. Phil. Thesis, Sheffield City Polytechnic with the University of Sheffield, UK.

AHMED, Z. N., 1994, Assessment of Residential Sites in Dhaka with respect to Gains. Ph. D. Thesis (unpublished), De Montfort University in Collaboration with the University of Sheffield, UK.

AHMED, Z. N., and ROY, G. S., 2007. Ventilation Potential: Examining the Effects of Growing Densification in the Tropics. Proceedings of Clima 2007 WellBeing Indoors, Helsinki, Finland, June, pp. 1-8.

BANGLADESH METEOROLOGICAL DEPARTMENT, Climate Division, 2012, Annual Climate Change Profile.

BASAK, J. K. et al., 2013, Climate Change in Bangladesh: A Historical Analysis of Temperature and Rainfall Data. Journal of Environment, 2(2), 41-46. 
BERKOVIC, S., YEZIORO, A., and BITAN, A., 2012, Study of thermal comfort in courtyards in a hot arid climate. Solar Energy, 86(5), 1173-1186

CASCONE, S., 2019, Green Roof Design: State of the Art on Technology and Materials. Sustainability, 11, 3020.

DEWAN, A. et al., 2007, Dynamics of land use/cover changes and the analysis of landscape fragmentation in Dhaka Metropolitan, Bangladesh. GeoJournal Spatially Integrated Social Sciences and Humanities, 77(3), 1-16.

DOULOS, L., SANTAMOURIS, M. and LIVADA, I., 2004, Passive cooling of outdoor urban spaces: The role of materials. Solar Energy, 77(2), 231-249.

ELAHI, F., and KHAN, N. I., 2015, A Study on the Effects of Global Warming in Bangladesh. International Journal of Environmental Monitoring and Analysis, 3(3), 118-121.

ETIKAN, I. et al., 2016, Comparison of convenience sampling and purposive sampling. American journal of theoretical and applied statistics, 5(1), 1-4.

GOVERNMENT OF THE NETHERLANDS, Ministry of Foreign Affairs of the Netherlands, 2018, Climate Change Profile Bangladesh.

GLENNON, R., 2017, The Unfolding Tragedy of Climate Change in Bangladesh, Date of Access: 29/03/2020. https://blogs.scientificamerican.com/guest-blog/the-unfolding-tragedy-of-climate-change-in-bangladesh/

HAN, K. T., 2019, Effects of Indoor Plants on the Physical Environment with Respect to Distance and Green Coverage Ratio. Sustainability, 11, 3679.

HASAN, A. B. M., and Rahman, M. Z., 2013, Change in Temperature over Bangladesh Associated with Degrees of Global Warming. Asian Journal of Applied Science and Engineering, 2(2), 161-174.

HOSSAIN, M. S., and LATIFEE, E. H., 2018, The Urban Heat Island (UHI) effects and mitigation measures. The Independent, 27 November.

HUMPRHEYS, M. et al., 2015, Standards for Thermal Comfort: Indoor Air Temperature Standards for the 21st Century (London, U.K.: Routledge).

ISTIAQUE, A., and KHAN, S. I., 2018, Impact of Ambient Temperature on Electricity Demand of Dhaka City of Bangladesh. Energy and Power Engineering, 10, 319-331.

ISMAIL, A., SAMAD, M. H. A., and RAHMAN, A. M. A., 2010, Potted Plants on Flat Roof as a Strategy to Reduce Indoor Temperature in Malaysian Climate. American Journal of Engineering and Applied Sciences, 3(3), 534-539.

JAPAN INTERNATIONAL COOPERATION AGENCY, 2010, Preparatory Survey Report on Dhaka Urban Transport Network Developmental Study in Bangladesh Final Report (Appendix Volume), Dhaka: Dhaka Transport Coordination Board.

JIM, C. Y., 2015, Assessing climate-adaptation effect of extensive tropical green roofs in cities. Landscape and Urban Planning, 138, 54-70.

KAMARUlZaman, N. et al., 2014, Green Roof Concepts as a Passive Cooling Approach in Tropical Climate- An Overview. E3S Web of Conferences, 3, 1028.

KARMALKAR, A. et al., 2012, UNDP Climate Change Country Profiles: Bangladesh. Date of Access: 29/03/2020.

cp/UNDP_reports/Bangladesh/Bangladesh.hires.reporr.pdf

http://www.geog.ox.ac.uk/research/climate/projects/uuun-

KARYONO, T. H., 1996, Thermal Comfort in the Tropical South East Asia Region. Architectural Science Review, 39(3), 135-139.

LIU, K., 2006, Thermal performance of green roofs in Canada. Date of Access: 14/04/2020. http://www.shef.ac.uk/landscape/greenroof/pdf/karenliu.pdf

LIU, K., and BASKARAN, B., 2003. Thermal performance of green roofs through field evaluation. Proceeding of the 1st North American Green Roofs Infrastructure Conference on Greening Rooftops for Sustainable Communities, Illinois, Chicago, May, pp. 29-30. 
MEHROTRA, D., AND MEHROTRA, R., 1995, Climate Change and hydrology with emphasis on the Indian subcontinent. Hydrologic Sciences Journal, 40, 231-241.

MOWLA, Q., 2010. Green Roof Concept for Eco-Sustainability in the Context of Urban Dhaka. Proceedings of GO GREEN, Lahore, Pakistan, October, pp. 1-13.

MRIDHA, A. M. M. H., 2002, A study of Thermal Performance of Operable Roof Insulation, with special reference to Dhaka. M. Arch Thesis (Unpublished), Bangladesh University of Engineering and Technology.

NIACHOU, A. et al., 2001, Analysis of the green roof thermal properties and investigation of its energy performance. Energy Build., 33, 719-729.

PONNI, M., and BASKAR, R., 2015, Comparative study of different types of roof and indoor temperatures in tropical climate. International Journal of Engineering and Technology, 7(2), 530-536.

RAHMAN, R., 2019, Impact of Global Warming: Perspective of Bangladesh. International Journal of Scientific Research and Engineering Development, 2(3), 906-911.

RASHID, R., and AHMED, M. H., 2009, Thermal performance of rooftop greenery system at the tropical climate of Malaysia: A case study of a 10 storied building R.C.C flat rooftop at UTM, Johor Bahru, Malaysia. Journal of Architecture and Built Environment, 37(1), 41-50.

ROSENZWEIG, C. et al., 2006. Green roofs in the New York metropolitan region: Research report. Columbia University Center for Climate Systems Research and NASA Goddard Institute for Space Studies, New York.

SHAJAHAN, A., 2012, An Investigation of indoor Thermal Comfort Range for Rural Houses of Dhaka Region. Working paper, Bangladesh University of Engineering and Technology.

SHISHEGAR, N., 2012. Green Roofs: Enhancing Energy and Environmental Performance of Buildings. Proceedings of International Conference on Clean Energy, Quebec, Canada, September, pp. 1-8.

TARIQ, T. and AHMED, Z., 2013. Effects of Roof Treatment on Thermal Performance of Residential Buildings in Dhaka. Proceedings of PLEA 2013 - 29th Conference: Sustainable Architecture for a Renewable Future, Munich, Germany, September, pp. 1-7.

TASHNIM, J., and ANWAR, M. A., 2016. Reasons and remides of heat island phenomena for Dhaka city: a review. Proceedings of 3rd International Conference on Civil Engineering for Sustainable Development (ICCESD 2016), Khulna, Bangladesh, February, pp. 228-234.

THE WORLD BANK, 2011, Bangladesh: Lighting Up Rural Communities, Date of Access: 29/03/2020. https://www.worldbank.org/en/results/2013/04/15/babanglade-lighting-up-rural-communities

THE WORLD BANK, 2018, Bangladesh: Rising Temperature Affects Living Standards of 134 Million People, Date of Access: 30/03/2020. https://www.worldbank.org/en/news/press-release/2018/09/26/bangladesh-risingtemperature-affects-living-standards-of-134-million-people

UNITED STATES AGENCY INTERNATIONAL DEVELOPMENT, 2015, Climate Change Information Fact Sheet BANGLADESH, Date of Access: 30/03/2020.

https://www.climatelinks.org/sites/default/files/asset/document/Bangladesh\%20Climate\%20Info\%20Fact\%20Sh eet_FINAL.pdf

U.S. DEPARTMENT OF THE INTERIOR, n.d., Green Roof Benefits, Date of Access: 29/03/2020. https://www.nps.gov/tps/sustainability/new-technology/green-roofs/benefits.htm

U.S. ENVIRONMENTAL PROTECTION AGENCY, 2018, Estimating the environmental effects of green roofs: A case study in Kansas City, Missouri, EPA 430-S-18-001, Date of Access: 29/03/2020. www.epa.gov/heat-islands/using-green-roofs-reduce-heat-islands

WILKINSON, S., and FEITOSA, R. C., 2015, Retrofitting Housing with Lightweight Green Roof Technology in Sydney, Australia, and Rio de Janeiro, Brazil. Sustainability, 7(1), 1081-1098. 